\begin{tabular}{|l|l|}
\hline $\begin{array}{l}\text { Postprint } \\
\text { Version }\end{array}$ & 1.0 \\
\hline Journal website & $\underline{\text { http://dx.doi.org/doi:10.1016/S0738-3991(00)00118-X }}$ \\
\hline Pubmed link & $\underline{\text { http://www.ncbi.nlm.nih.gov/pubmed/10900370 }}$ \\
\hline DOI & $10.1016 /$ S0738-3991(00)00118-X \\
\hline
\end{tabular}

This is a NIVEL certified Post Print, more info at http://www.nivel.eu

\title{
Evaluative research on palliative support teams: a literature review
}

\author{
ANNEKE L. FRANCKE \\ NIVEL, Dutch Centre for Primary Health Care, 3500 BN Utrecht, The Netherlands
}

\begin{abstract}
Sixteen studies on the effectiveness of palliative support teams were analyzed. It was established that in most cases uncontrolled designs with repeated measurements were used. The assessment methods varied strongly. However, the Support Team Assessment Schedule was the most frequently used instrument. Effects reported on patients' physical symptoms, such as pain, were for the most part positive. Fewer effects were reported regarding psychosocial and spiritual problems of patients and relatives. For instance, various studies indicated that feelings of anxiety did not diminish after referral to a palliative support team. Results about the effects on use and costs of health care services did not point in a clear direction. Accordingly it is unclear whether palliative support teams reduce or increase care consumption and costs. Given the sometimes contradictory findings and the small number of studies conducted, future high-quality research into the effectiveness of palliative support teams is needed.
\end{abstract}

\section{INTRODUCTION}

The first palliative support teams were founded under the influence of the "hospice movement' about 20 years ago in England, Canada and the United States ${ }^{[1]}$ and ${ }^{[2]}$. Palliative support teams can be defined as teams that give advice about palliative care and often also practical help, on request, to patients or care providers. Most teams also support relatives, since a terminal illness causes anxiety and stress not only to the patient but also to the family. The teams work in the hospital and/or in the community, often using the facilities of existing services. Support teams have no beds of their own. Consequently, when compared with an inpatient hospice or palliative care unit, support teams may be inexpensive to run. Moreover, a support team can bring the principles of specialized, integrated palliative care to patients at home and in the hospital at an early stage. This can make palliative support teams 
attractive to care providers who lack specialized expertise about palliative care, but who wish to continue to care for their own patients ${ }^{[1]}$ and ${ }^{[3]}$.

At present hundreds of palliative support teams are active in the English-speaking countries mentioned above ${ }^{[2]},{ }^{[4]}$ and ${ }^{[5]}$. Related to the current strong interest in the quality of care for the dying, palliative support teams have been found recently in many other western countries (e.g., Belgium, Spain and The Netherlands) ${ }^{[6]}$ and ${ }^{[7]}$. In The Netherlands, for instance, in a descriptive study undertaken in 1998, nine palliative support teams were located, all of whom had started in the previous five years ${ }^{[8]}$. The rise of palliative support teams in The Netherlands is related to the Dutch government policy, with its strong focus on the integration of palliative care into the regular (non-private) health care system. Since palliative support teams are expected to contribute to the broadening of expertise, skills and the options of regular health professionals (amongst others); this corresponds very well with the government's policy.

The ultimate goal of palliative support teams is to reduce physical, psychosocial and spiritual suffering among those in the last phase of their life. Research on the effectiveness of palliative support teams is important because it can give insight into whether this aim is being met. In addition, evaluative studies can give insight into the extent to which palliative support teams influence the consumption and cost of health care. This is important since it is often suggested that palliative support teams may contribute to savings of health care costs and charges by relieving pain and other symptoms, reducing hospital admissions and in-patient length of stay and avoiding unnecessary investigations or interventions ${ }^{[2]}$.

The direct reason for the review of the literature presented was that persons involved in a Dutch palliative support team had plans for an evaluative study, but had insufficient insight into what methods and instruments were appropriate. In this article, we hope that other persons who are planning such a study will also benefit from the methodological insights derived from our review of evaluative research on palliative support teams. In addition, we aim to shed more light on the effectiveness of palliative support teams. The following research questions will be addressed:

- What evaluative methods and instruments have been used in evaluative studies of palliative support teams?

- What evaluative outcomes were reported with respect to: (a) physical, psychosocial or spiritual problems of patients and relatives? (b) consumption and cost of health care?

In the next section the search of the literature is discussed. Subsequently, the results of the review of the literature are presented. The article closes with some conclusions and reflections on appropriate evaluative methods and on the effectiveness of palliative support teams.

\section{METHODS}

\subsection{Search and selection of literature}

The main sources for references were Medline and Cinahl (CD-ROM, 1990 to 1998) and reference lists in the publications on palliative support teams. The following (combined) keywords were used for the searches in Medline and Cinahl: palliative team; palliative care team; support team; supportive team; hospice team. Selection criteria for inclusion in the review of the literature were: 
1. the publication relates to a finished evaluative study focusing on the outcomes of a palliative support team on patients, relatives or consumption/cost of health care. For reasons of (in)comparability, purelyprocess-oriented evaluative studies (e.g., 3) were omitted from our review;

2. the team evaluated provides advice and/or practical support to terminal patients, relatives or care providers, on physical, as well as psychosocial or spiritual care aspects. Evaluative studies on teams focusing only on aspects of palliative care (e.g., Pain management or home care technology) were excluded;

3. the evaluative study was published in English, Dutch, German or French.

Strict methodological selection criteria were not employed because the amount of literature available on relevant evaluative studies appeared to be modest (there were for instance no German or French studies found in this field), and consequently both controlled and uncontrolled studies were included.

\section{RESULTS}

\subsection{The number of studies and the general characteristics of the teams}

A total of 16 evaluative studies met the criteria used and were included in the review of the literature [6], [9], [10], [11], [12], [13], [14], [15], [16], [17], [18], [19], [20], [21], [22] and [23]. The teams assessed were discussed in the relevant articles under different names, such as ' palliative support team', 'hospice team' or 'support team' (see Table 1). In the following sections, we will mostly use the umbrella term 'palliative support team'.

\section{[TABLE 1]}

The teams studied all employed a multidisciplinary approach: the core of the teams in all cases consisted of nurses, often closely collaborating with physicians and sometimes also with pastoral and social workers and paramedics. All teams were either hospital-based or connected to community care organizations.

\subsection{Design and sample of the studies reviewed}

In six of the sixteen studies reviewed, a design with control or comparison groups was used (see Table 1). In one of these studies the groups were formed by random allocation. In 10 studies an uncontrolled design was used, often with repeated (prospective or retrospective) measurements. The research samples covered patients, relatives or care providers. Sample sizes varied from 10 to 1716 persons.

\subsection{Instruments for assessing physical, psychosocial or spiritual problems}

A wide range of instruments was used to obtain insight into the effects on symptoms and problems of patients and/or their relatives (see Table 1). For example, the Support Team Assessment Scale was used in 5 out of 16 of the studies examined.

The STAS is a useful, valid and reliable questionnaire for 'clinical audit' in the palliative phase ${ }^{[24]}$ and ${ }^{[25]}$. The STAS comprises, among other things, items about pain and symptom control, and problems of the immediate family. In the cases 
concerned, the STAS list was sometimes filled in on the basis of patient reactions, and sometimes on the reactions of carers (see Table 1).

The Memorial Symptom Assessment Scale was used in the study by Abrahm et al. ${ }^{[9]}$. This questionnaire is developed by Portenoy and colleagues ${ }^{[26]}$ and measures various physical and psychosocial problems, among others, pain, lack of energy, worrying, sadness and nervousness. The questionnaire appears to be appropriate for administration to various groups of cancer patients and is valid and reliable ${ }^{[26]}$. In

Abrahm's study the MSAS was reviewed by nursing staff with the patient ${ }^{[9]}$. In the Ellershaw et al. study ${ }^{[16]}$ the Palliative Care Assessment Tool was applied. The PACA consists of a form developed by Ellershaw and colleagues, on which information about the effects of symptoms on daily life (derived from an interview of carers with the patient) can be summarized. Among the symptoms covered by the PACA are pain, nausea, vomiting, constipation, anorexia, dyspnoea, immobility and insomnia. Its validity, reliability and applicability to terminal patients has been demonstrated $^{[16]}$.

Higginson and Hearn ${ }^{[19]}$ used the Karnofsky Performance Scale developed by Karnofsky and colleagues ${ }^{[27]}$ for the study of effects of palliative therapies for cancer patients. Carers can indicate on the form the extent to which patients are capable of moving, undertaking normal daily activities and able to care for themselves. In addition to the KPS, the STAS (see above) was also used in the Higginson and Hearn study. There was a notable lack of correlation between the KPS and STAS scores, which is an indication of limited concurrent validity between the KPS and STAS. In the Jarvis and Burge study ${ }^{[21]}$ the Symptom Distress Scale ${ }^{[28]}$ was used to derive information from patients about symptoms. This questionnaire has demonstrated validity and reliability and measures for nausea, pain, appetite, insomnia, fatigue, constipation, concentration, appearance, outlook, coughing and breathing. The instrument was established as usable for populations of terminal patients ${ }^{[21]}$. The McGill Pain Questionnaire ${ }^{[29]}$, a valid and reliable instrument, was used for insight into patients' pain complaints in the study of McWhinney et al. ${ }^{[23]}$. Another instrument used in the aforementioned study to get information from patients was the Melzack nausea questionnaire. This is a valid instrument for measuring the intensity and other qualities of nausea, originally developed for use among cancer patients with chemotherapy ${ }^{[30]}$. In addition, McWhinney and colleagues used the Functional Living Index-Cancer, a valid instrument for getting insight into physical and psychosocial state and sociability of cancer patients ${ }^{[31]}$. Relatives were questioned by McWhinney and colleagues using the Center for Epidemiological StudiesDepression Scale, a valid and reliable self-report depression scale for research in the general population ${ }^{[32]}$.

In the study by Hockley et al. ${ }^{[20]}$ a self-developed symptom list, semi-structured interview and the Mood Adjective Check List was used to elicit information from patients or relatives about symptoms or problems. On the basis of the publication of Hockley et al. it is not clear to what extent these instruments are valid, reliable or applicable.

\subsection{Instruments used for assessing consumption and cost of health care}

In order to gain insight into the effects on the use and cost of care, clinical/financial records or standardized data forms were analyzed in the majority of studies (see Table 1). In these studies little or no information about the nature of the records 
or forms used is provided. The evaluative study by Ballinckx [6] is an exception in this respect. In this study the researchers used a data form that is applied widely in Belgian palliative care practice. In the majority of the studies, the manner in which the data from the records or forms are scored or analyzed is not specified. The studies by Campbell [14] and by Field and colleagues [17] are exceptions. In these studies, existing criteria and scoring systems such as the 'Therapeutic Interventions Scoring System' developed by Keene and Cullen [33] were used.

\subsection{Outcomes regarding physical, psychosocial or spiritual problems}

Ten out of the 16 studies use pain or other physical complaints as an outcome measure (see ${ }^{\text {Table } 1}$ ). Higginson and Hearn ${ }^{[19]}$, for example, assessed 11 support teams in England and Ireland. It turned out that after 2 weeks of guidance by a support team, the pain of the terminal cancer patients being studied was significantly reduced. There was no question of unbearable pain in any of the patients. Butters et al. assessed the results of two support teams for people with AIDS/HIV related illness in London. They also established that pain scores as well as scores concerning control of other symptoms such as weakness, diarrhoea, and visual problems, improved significantly after referral to a palliative support team. Most other studies in which pain and other physical complaints were determined, similarly report positive results (see Table 1). However, the study by McWhinney et al. ${ }^{[23]}$, the only study using a randomized design, is an exception in this regard. McWhinney and colleagues found no significant changes in pain and nausea complaints after referral to a support team in Ontario. The absence of significant statistical results was attributed by the authors to the high numbers of non-responders and drop-outs. Out of the 307 referred patients only 146 wanted or were eligible to participate, and from the 146 randomized, 53 dropped out after less than 1 month (mostly because of death).

In 7 out of the 16 studies, attention is (also) paid to the psychosocial or spiritual problems of the patients and their relatives (see Table ${ }^{1}$ ). For example, in the study by Abrahm et al. ${ }^{[9]}$ it appeared that $40-61 \%$ of the newly identified psychosocial and spiritual problems were relieved after referral to a palliative support team in Philadelphia. However, the team in question was much more successful in relieving medical problems (see Table 1). Higginson et al. ${ }^{[18]}$ studied the effectiveness of two support teams in London and Kent. Family anxiety and psychological problems of patients did not appear to diminish after referral to one of the support teams. The results of Ballinckx ${ }^{[6]}$ point in the same direction to a large extent. Ballinckx demonstrated that anxiety in the patient and family did not improve after referral to a Belgian support team. In contradistinction, Butters et al. ${ }^{[12]}$ could point to significant changes in the anxiety level of patients in this case, after referral to a support team for AIDS-patients in London.

\subsection{Outcomes regarding consumption and cost of health care}

The consequences for health care consumption and cost has been assessed in five studies (see Table 1 ). The studies by Campbell ${ }^{[14]}$, Carlson et al. ${ }^{[15]}$ and Field et al. ${ }^{[17]}$ concerned a support team in a hospital in Detroit intended for people who were not expected to survive their stay in hospital. The efforts of the support team meant that patients could be transferred from intensive care units to other, less intensive wards. Also fewer high-tech interventions and diagnostic tests needed to be 
carried out. In Lonberger's et al. research project ${ }^{[22]}$ it was also established that daily charges were significantly reduced after patients were referred to a hospital-based palliative support team in Columbia, Missouri. The greatest reduction of charges resulting from implementation of the team was found to be in laboratory and radiology testing.

However, the results of Bennett and Corcoran's study ${ }^{[10]}$ suggest that the introduction of a support team can also lead to an increase in the consumption of care. The above named authors demonstrated that after a support team based in a hospital in Leeds began its work, more patients in the early stage of sickness were referred to a local home care service specializing in palliative care.

\section{CONCLUSIONS AND DISCUSSION}

Sixteen studies on the effectiveness of palliative support teams were analyzed. These studies indicated that pain and other physical complaints often decrease, whereas psychosocial and spiritual problems are lesser reduced after referral to a palliative support team. The reason for this last finding is not clear. It may be that palliative support teams are better equipped to deal with physical complaints than, for example, anxiety about further decline and death.

The results of the few studies on the effects on consumption and cost of health care did not point in a clear direction. In our opinion, in future studies comparisons could more often be made between the consumption of care before and after a palliative support team has been brought into action. Evaluative studies that also pay attention to efficiency aspects could help policy makers to make priorities with regards to the composition and activities of a support team. However, in that respect it must never be forgotten, that especially for terminal patients, it is not cost efficiency considerations but the improvement of the quality of living and dying that must be of primary importance.

Future research also seems necessary because the number of studies to date is relatively small and the results do not point in a clear direction. However, the setting up of outcome-oriented evaluative studies will not always be simple. The patient groups guided by palliative support teams are often limited in size, and consequently samples sizes are often small (see Table 1). In addition, the high incidence of nonresponse and drop-outs among seriously sick patients appears to create methodological problems. This all can make it difficult to derive statistically significant findings ${ }^{[23]}$. As we consider the research designs used, it is also apparent that very little use is made of (randomized) control or comparison groups (see Table 1). Ethical considerations often make it very difficult to form randomized control groups. One cannot withhold interventions that one assumes will improve the quality of the last phase of life from terminal patients. As an alternative in some of the studies reviewed a non-controlled design using multiple measurements (retrospective or prospective) is often chosen. In the literature ${ }^{[34]}$ the value of such designs, also in the case of palliative care, is questioned. However, we judge them to be a reasonable alternative, since in the case of terminal patients spontaneous improvements are rare. For that reason, a study without control groups, but with repeated measurements can be used to make statements about effects. One necessary requirement for that is that initial measurements are performed before or around the time of referral to the team. 
Francke, A.L. Evaluative research on palliative support teams: a literature review. Patient Education and Counseling: 2000, 41(1), 83-91

The particular advantage of a prospective design with repeated measurements is that it is appropriate for feedback to team members on time. By giving feedback on interim results, the quality of the activities of a support team can be improved. However, interim feedback may result in changes in the support of a team. To gain insight into the nature of changes in a team's interventions, it is necessary to determine how the team evolves in the course of time. Accordingly, good, complete records or registration forms need to be kept.

As we look over the instruments used, it is striking that (except the STAS) very few similar questionnaires are used. In order to facilitate comparability we recommend that in future studies in this area more of the same type of instruments should be used. The STAS may be a good choice, because this instrument covers a rather broad range of symptoms and problems in terminal patients. However, the STAS (like most other instruments frequently used in this field) is developed and mainly tested within the framework of clinical audit ${ }^{[35]}$. Further insight is needed into the STAS' methodologic properties and usefulness within the context of scientific research.

Special attention is recommended for the STAS' sensitivity in measuring psychosocial and spiritual symptoms, since it is remarkable that in research in which the STAS was used more often effects were established regarding physical outcomes than effects regarding psychosocial and spiritual variables.

Serious consideration must also be given to the person who fills in the questionnaires. Probably in order not to overburden the patient, in the studies reviewed it was sometimes chosen to let the carers fill in the forms. However, there are indications that in many cases the impression of carers only moderately agrees with the experience of the patient ${ }^{[24]}$. One needs to take this into account in the choice of instruments and the interpretation of results. 
Francke, A.L. Evaluative research on palliative support teams: a literature review. Patient Education and Counseling: 2000, 41(1), 83-91

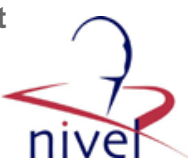

\section{REFERENCES}

[1] Bates T, Hoy AM, Clarke DG, Laird PP. The St. Thomas' hospital terminal care support team. A new concept of hospice care. Lancet, May 30 1981:1201-1203.

[2] W.M. O'Neill, P. O'Connor, E.J. Latimer Hospital palliative care services: three models in three countries J Pain Sympt Manag, 7 (7) (1992), pp. 406-413

[3] M.H. Bromberg, I. Higginson Bereavement follow-up: what do palliative support teams actually do? J Pall Care, 12 (1) (1996), pp. 12-17

[4] I. Higginson Palliative care: a review of past changes and recent trends J Publ Health Med, 15 (1) (1993), pp. 3-8

[5] R.G. Twycross Palliative care. A new specialist development in oncology IKR-Bull, 19 (2/3) (1995), pp. 6-9

[6] M. Ballinckx Resultaten van een pallatief support team in een algemeen ziekenhuis na drie jaar werking (Results of a palliative support team in a general hospital)

Verpleegkundigen en Gemeenschapszorg, 51 (3) (1995), pp. 105-109

[7] X. Gomez-Batiste, M.D. Fontanals, J. Roca et al. Catalonia WHO demonstration project on palliative care implementation 1990-1995: results in 1995 J Pain Sympt Manag, 12 (2) (1996), pp. 73-78

[8] Francke AL, Hulshof NA. Ondersteuningsteams palliatieve zorg (supportive team in palliative care). Een studie naar de stand van zaken. Utrecht/Maastricht: NIVEL/AZM, 1998.

[9] J.L. Abrahm, J. Callshan, K. Rossetti, L. Pierre The impact of a hospice consultation team on the care of veterans with advanced cancer J Pain Sympt Manag, 12 (1996), pp. 23-31

[10] M. Bennett, G. Corcoran The impact on community palliative care services of a hospital palliative care team Pall Med, 8 (1994), pp. 237-244

[11] E. Bruera, K. MacMillan, J. Hanson, R.N. MacDonald Palliative care in a cancer center: results in 1984 versus 1987 J Pain Sympt Manag, 5 (1) (1990), pp. 1901-1905

[12] E. Butters, I. Higginson, R. George, A. Smits, M. McCarthy Assessing the symptoms, anxiety and practical needs of HIVIAIDS patients receiving palliative care Qual Life Res, 1 (1992), pp. 47-51

[13] E. Butter, I. Higginson Two HIVIAIDS community support teams: patient characteristics, problems at referral and during the last 6 weeks of life Aids Care, 7 (5) (1995), pp. 593-602

[14] M.L. Campbell Program assesment through outcomes analysis: Efficacy of a comprehensive supportive care team for end-of-life care AACN Clinical Issues, 7 (1) (1996), pp. 159-167

[15] R.W. Carlson, L. Devich, R.R. Frank Development of a comprehensive supportive care team for the hopelessly ill on a university medical service J Am Med Assoc, 259 (3) (1988), pp. 378-383

[16] J.E. Ellershaw, S.J. Peat, L.C. Boys Assessing the effectiveness of a hospital palliative care team Pall Med, 9 (1995), pp. 145-152

[17] B.E. Field, L.E. Devich, R.W. Carlson Impact of a comprehensive supportive care team on management of hopelessly ill patients with multiple organ failure

Chest, 2 (1996), pp. 353-356

[18] I.J. Higginson, A.M. Wade, M. McCarthy Effectiveness of two palliative support teams

J Publ Health Med, 14 (1) (1992), pp. 50-56 
Francke, A.L. Evaluative research on palliative support teams: a literature review. Patient Education and Counseling: 2000, 41(1), 83-91

[19] I.J. Higginson, J. Hearn A multicenter evaluation of cancer pain control by palliative care teams J Pain Sympt Manag, 14 (7) (1997), pp. 29-35

[20] J. Hockley, R. Dunlop, R.J. Davies Survey of distressing symptoms in dying patients and their families in hospital and the response to a symptom control team Br Med J, 26 (1988), pp. $1715-1717$

[21] H. Jarvis, F.I. Burge Evaluating a palliative care program: methodology and limitations J Pall Care, 12 (2) (1996), pp. 23-33

[22] E.A. Lonberger, C.L. Russell, S.M. Burton The effects of palliative care on patient charges J Nurs Admin, 27 (11) (1997), pp. 23-26

[23] I.R. McWhinney, M.J. Bass, A. Donner Evaluation of a palliative care service: problems and pitfalls Br Med J, 309 (1994), pp. 1340-1342

[24] I.J. Higginson, M. McCarthy Validity of the support team assessment schedule: do staffs' ratings reflect those made by patients or their families? Pall Med, 7 (7) (1993), pp. 219-228 [25] I.J. Higginson Clinical audit and organizational audit in palliative care Canc Surv, 21 (1994), pp. 233-245

[26] R.K. Portenoy, H.T. Thaler, A.B. Kornblith et al. The Memorial Symptom Assessment Scale; an instrument for the evaluation of symptom prevalence, characteristics and distress Eur J Cancer, 30A (1994), pp. 1326-1336

[27] D.A. Karnofsky, W.H. Albelman, L.F. Craver, J.H. Burchenal The use of nitrogen mustards in the palliative treatment of carcinoma Cancer, 1 (1948), pp. 634-656

[28] R. McCorkle, K. Young Development of a symptom distress scale Canc Nurs, 3 (2) (1978), pp. 8-13

[29] R. Melzack The McGill pain questionnaire: major properties and scoring methods Pain, 1 (1975), pp. 277-299

[30] R. Melzack, Z. Rosberger, M.L. Lois Hollingsworth, M. Thirlwell New approaches to measuring nausea Can Med Ass J, 133 (15) (1985), pp. 755-761

[31] H. Schipper, J. Clinch, A. McMurray, M. Levitt Measuring the quality of life of cancer patients: the Functional Living Index-Cancer: development and validation Clin Oncol, 2 (5) (1984), pp. 472-482

[32] L. Sawyer Radloff The CES-D Scale: a self-report depression scale for research in the general population Appl Psych Meas, 1 (3) (1977), pp. 385-401

[33] A.R. Keene, D.J. Cullen Therapeutic intervention scoring system: update 1983 Critical Care Med, 11 (1983), pp. 1-3

[34] G.C. Rinck, A.M. van den Bos, J. Kleijnen, H.J.C.J.M. de Haes, E. Schade, C.H.N. Veenhof Methodologic issues in effectiveness research on palliative cancer care: a systematic review Clin Oncol, 15 (4) (1997), pp. 1697-1707

[35] J. Hearn, I.J. Higginson Outcome measures in palliative care for advanced cancer patients: a review J Publ Health Med, 19 (1997), pp. 193-199 
Francke, A.L. Evaluative research on palliative support teams: a literature review. Patient Education and Counseling: 2000, 41(1), 83-91

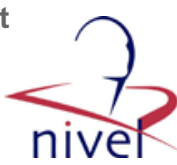

TABLES

Table 1. Outcome oriented evaluation studies on palliative support teams

\begin{tabular}{|c|c|c|c|}
\hline Authors/team & Design & Sample/instruments & Outcomes \\
\hline Abrahm et al. '96[9]: & prospective design & 75 cancer patients: & $\begin{array}{l}\text { after referral to } \\
\text { team: }\end{array}$ \\
\hline $\begin{array}{l}\text { ‘hospice } \\
\text { consultation team’ } \\
\text { of a hospital }\end{array}$ & with repeated mea- & - MSAS & $\begin{array}{l}\text { - many new } \\
\text { medical, } \\
\text { psychosocial and }\end{array}$ \\
\hline $\begin{array}{l}\text { in Philadelphia. } \\
\text { Activities: }\end{array}$ & surements, no con- & (derived from patients) & $\begin{array}{l}\text { spiritual problem } \\
\text { were identified }\end{array}$ \\
\hline $\begin{array}{l}\text { - advice/practical } \\
\text { support for } \\
\text { inpatients }\end{array}$ & trol group & - data collection form & $\begin{array}{l}-85 \% \text { of new } \\
\text { identified } \\
\text { medical/nursing }\end{array}$ \\
\hline and care providers & problems resolved & & \\
\hline - family support & $\begin{array}{l}-40-61 \% \text { of new } \\
\text { identified }\end{array}$ & & \\
\hline $\begin{array}{l}\text { - coordination of } \\
\text { care }\end{array}$ & $\begin{array}{l}\text { psychosocial/spiritual } \\
\text { problems resolved }\end{array}$ & & \\
\hline $\begin{array}{l}\text { - education for care } \\
\text { providers }\end{array}$ & $\begin{array}{c}\text { - 90\% of patients with } \\
\text { unacceptable pain }\end{array}$ & & \\
\hline \multicolumn{4}{|l|}{$\begin{array}{l}\text { achieved acceptable } \\
\text { pain relief }\end{array}$} \\
\hline \multicolumn{4}{|l|}{$\begin{array}{l}\text { - in } 96 \% \text { of patients } \\
\text { with opioid- } \\
\text { induced side }\end{array}$} \\
\hline \multicolumn{4}{|l|}{$\begin{array}{l}\text { effects problems } \\
\text { were resolved }\end{array}$} \\
\hline \multicolumn{4}{|l|}{$\begin{array}{l}\text { (no statistical testing } \\
\text { of outcomes) }\end{array}$} \\
\hline Ballinx '95[6]: & prospective design & $\begin{array}{l}109 \text { terminal patients } \\
\text { with }\end{array}$ & $\begin{array}{l}\text { after referral to } \\
\text { team: }\end{array}$ \\
\hline $\begin{array}{l}\text { 'palliative support } \\
\text { team' of a hospital }\end{array}$ & with repeated mea & $\begin{array}{l}\text { cancer, heart/lung } \\
\text { failure, }\end{array}$ & $\begin{array}{l}\text { - total STAS- } \\
\text { scores improved } \\
\text { in } 82 \%, \text { didn't }\end{array}$ \\
\hline $\begin{array}{l}\text { in Belgium. } \\
\text { Activities: }\end{array}$ & surements, no & stroke etc.: & $\begin{array}{l}\text { change in } 2 \% \text { and } \\
\text { worsened in } 16 \%\end{array}$ \\
\hline $\begin{array}{l}\text { - advice/practical } \\
\text { support for } \\
\text { inpatients }\end{array}$ & control group & - STAS & $\begin{array}{l}\text { - no significant } \\
\text { changes in } \\
\text { physical } \\
\text { symptoms }\end{array}$ \\
\hline and care providers & (derived from patients & $\begin{array}{l}\text { other than pain, anxiety } \\
\text { and communication }\end{array}$ & \\
\hline - family support & and family) & $\begin{array}{l}\text { between patient and } \\
\text { family }\end{array}$ & \\
\hline $\begin{array}{l}\text { - coordination of } \\
\text { care }\end{array}$ & - data collection form & & \\
\hline $\begin{array}{l}\text { Bennett \& } \\
\text { Corcoran '94[10]: }\end{array}$ & retrospective & 1716 terminal patients: & $\begin{array}{l}\text { after introduction } \\
\text { of team: }\end{array}$ \\
\hline 'palliative care team' & design, with a & - clinical records & - increase in the \\
\hline
\end{tabular}


Francke, A.L. Evaluative research on palliative support teams: a literature review. Patient Education and Counseling: 2000, 41(1), 83-91

\begin{tabular}{|c|c|c|c|}
\hline Authors/team & Design & Sample/instruments & Outcomes \\
\hline of a hospital in & & & $\begin{array}{l}\text { number of } \\
\text { patients being }\end{array}$ \\
\hline Leeds. Activities: & historical & $\begin{array}{l}\text { referred to a palliative } \\
\text { home care service at } \\
\text { an }\end{array}$ & \\
\hline $\begin{array}{l}\text { - advice/practical } \\
\text { support for in- and }\end{array}$ & comparison group & $\begin{array}{l}\text { earlier stage }(P<0.004) \text {, } \\
\text { resulting in more }\end{array}$ & \\
\hline $\begin{array}{l}\text { outpatients and care } \\
\text { providers }\end{array}$ & $\begin{array}{l}\text { workload for the home } \\
\text { care nurses }\end{array}$ & & \\
\hline \multicolumn{4}{|l|}{$\begin{array}{l}\text { - referral of patients } \\
\text { to other care }\end{array}$} \\
\hline \multicolumn{4}{|l|}{ providers } \\
\hline $\begin{array}{l}\text { Bruera et al. } \\
\text { '90[11]: }\end{array}$ & retrospective design & 98 terminal patients: & $\begin{array}{l}\text { after referral to } \\
\text { team: }\end{array}$ \\
\hline $\begin{array}{l}\text { 'palliative care team' } \\
\text { of a hospital in }\end{array}$ & with 2 comparison & - clinical records & $\begin{array}{l}\text { - poor pain control } \\
\text { was observed in } \\
42 \% \text { of }\end{array}$ \\
\hline $\begin{array}{l}\text { Edmonton. } \\
\text { Activities: }\end{array}$ & groups (1 group & $\begin{array}{l}\text { patients in } 1984 \text { versus } \\
26 \% \text { in } 1987(P<0.01)\end{array}$ & \\
\hline $\begin{array}{l}\text { - advice for } \\
\text { inpatients and care } \\
\text { providers }\end{array}$ & referred to team in ' 84 , & & \\
\hline \multicolumn{4}{|l|}{$\begin{array}{l}\text { and } 1 \text { group referred } \\
\text { in '87) }\end{array}$} \\
\hline $\begin{array}{l}\text { Butters et al. } \\
\text { '92[12]: }\end{array}$ & prospective design & 140 AIDS/HIV patients: & $\begin{array}{l}\text { after referral to } \\
\text { team: }\end{array}$ \\
\hline $\begin{array}{l}2 \text { 'community } \\
\text { support teams' of a } \\
\text { hospital }\end{array}$ & with repeated mea- & - STAS & $\begin{array}{l}\text { - STAS-scores } \\
\text { regarding pain, } \\
\text { symptom }\end{array}$ \\
\hline $\begin{array}{l}\text { and a community } \\
\text { care organizations } \\
\text { in }\end{array}$ & surements, no & (filled in by staff) & $\begin{array}{l}\text { control, anxiety } \\
\text { and practical aid } \\
\text { improved }\end{array}$ \\
\hline London. Activities: & control groups & - clinical records & $(P<0.05)$ \\
\hline $\begin{array}{l}\text { - advice/practical } \\
\text { support for AIDS- } \\
\text { patients }\end{array}$ & $\begin{array}{l}\text { - although scores } \\
\text { improved, sufficient }\end{array}$ & & \\
\hline $\begin{array}{l}\text { and care providers } \\
\text { in the hospital or }\end{array}$ & $\begin{array}{l}\text { symptom control was } \\
\text { difficult to achieve }\end{array}$ & & \\
\hline \multicolumn{4}{|l|}{ community } \\
\hline \multicolumn{4}{|l|}{ - counselling } \\
\hline \multicolumn{4}{|l|}{ - family support } \\
\hline \multicolumn{4}{|l|}{$\begin{array}{l}\text { - education for care } \\
\text { providers }\end{array}$} \\
\hline \multicolumn{4}{|l|}{$\begin{array}{l}\text { Butters \& } \\
\text { Higginson '95[13]: }\end{array}$} \\
\hline $\begin{array}{l}2 \text { ‘community } \\
\text { support' in London. }\end{array}$ & - STAS & $\begin{array}{r}\text { - in } 1 \text { team STAS- } \\
\text { scores regarding }\end{array}$ & \\
\hline
\end{tabular}


Francke, A.L. Evaluative research on palliative support teams: a literature review. Patient Education and Counseling: 2000, 41(1), 83-91

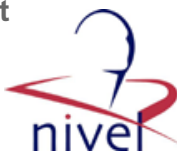

\begin{tabular}{|c|c|c|c|}
\hline Authors/team & Design & Sample/instruments & Outcomes \\
\hline & & family & \\
\hline $\begin{array}{l}\text { Activities: see } \\
\text { Butters et al. '92 }\end{array}$ & (filled in by staff) & $\begin{array}{l}\text { anxiety and symptom } \\
\text { control worsened }\end{array}$ & \\
\hline - clinical records & $(P<0.0003$ and $P<0.04)$ & & \\
\hline \multicolumn{4}{|l|}{$\begin{array}{l}\text { - in other team } \\
\text { STAS-scores } \\
\text { regarding }\end{array}$} \\
\hline \multicolumn{4}{|l|}{$\begin{array}{l}\text { spiritual problems, } \\
\text { communication } \\
\text { between }\end{array}$} \\
\hline \multicolumn{4}{|l|}{$\begin{array}{l}\text { patient and family } \\
\text { and patient insight }\end{array}$} \\
\hline \multicolumn{4}{|l|}{$\begin{array}{l}\text { improved } \\
\qquad(\text { all } P<0.04)\end{array}$} \\
\hline Campbell '96[14]: & retrospective design & $\begin{array}{l}35 \text { (??) terminal } \\
\text { patients: }\end{array}$ & $\begin{array}{l}\text { after introduction } \\
\text { team: }\end{array}$ \\
\hline $\begin{array}{l}\text { 'comprehensive } \\
\text { supportive care } \\
\text { team' of }\end{array}$ & with 2 comparison & - clinical records & $\begin{array}{l}\text { - reduction in } \\
\text { hospital charges } \\
\text { and costs }\end{array}$ \\
\hline $\begin{array}{l}\text { a hospital in Detroit. } \\
\text { Activities: }\end{array}$ & groups ( 1 before & 35 relatives: & $\begin{array}{l}\text { - length of stay on } \\
\text { intensive care } \\
\text { unit reduced }\end{array}$ \\
\hline $\begin{array}{l}\text { - advice/practical } \\
\text { support for } \\
\text { inpatients- }\end{array}$ & and 1 after & $\begin{array}{l}\text { - questionnaire } \\
\text { designed }\end{array}$ & $\begin{array}{l}\text { - fewer therapeutic } \\
\text { interventions } \\
\text { provided }\end{array}$ \\
\hline family support & introduction team) & by the researchers & $\begin{array}{l}\text { - fewer diagnostic } \\
\text { tests performed }\end{array}$ \\
\hline $\begin{array}{l}\text { - education for care } \\
\text { providers }\end{array}$ & 27 care providers & $\begin{array}{l}\text { - relatives are satisfied } \\
\text { with care }\end{array}$ & \\
\hline $\begin{array}{l}\text { - questionnaire } \\
\text { designed }\end{array}$ & $\begin{array}{l}\text { - care providers are } \\
\text { satisfied with the }\end{array}$ & & \\
\hline by the researchers & $\begin{array}{l}\text { availability and } \\
\text { operation of team }\end{array}$ & & \\
\hline \multicolumn{4}{|l|}{$\begin{array}{l}\text { (unclear whether } \\
\text { statistical testing }\end{array}$} \\
\hline \multicolumn{4}{|l|}{ is performed) } \\
\hline $\begin{array}{l}\text { Carlson et al. } \\
\text { '88[15]: }\end{array}$ & retrospective design & 62 terminal patients with & $\begin{array}{l}\text { after introduction } \\
\text { team: }\end{array}$ \\
\hline $\begin{array}{l}\text { ‘comprehensive } \\
\text { supportive care } \\
\text { team' of }\end{array}$ & with 3 comparison & $\begin{array}{l}\text { global anoxic brain } \\
\text { injury: }\end{array}$ & $\begin{array}{l}\text { - reduction in } \\
\text { hospital charges } \\
\text { and costs }\end{array}$ \\
\hline $\begin{array}{l}\text { a hospital in Detroit. } \\
\text { Activities: see }\end{array}$ & groups ( 1 before & - clinical records & $(P<0.05)$ \\
\hline Campbell, 1996. & introduction team, & $\begin{array}{l}\text { - length of stay reduced } \\
\quad(P<0.05)\end{array}$ & \\
\hline 1 shortly and 1 & $\begin{array}{l}\text { - no effect on survival } \\
\text { rate }\end{array}$ & & \\
\hline \multicolumn{4}{|l|}{ longer afterwards) } \\
\hline & prospective design & 125 terminal cancer & after referral to \\
\hline
\end{tabular}


Francke, A.L. Evaluative research on palliative support teams: a literature review. Patient Education and Counseling: 2000, 41(1), 83-91

\begin{tabular}{|c|c|c|c|}
\hline Authors/team & Design & Sample/instruments & Outcomes \\
\hline Ellershaw '95[16]: & & & team: \\
\hline $\begin{array}{l}\text { ‘advisory palliative } \\
\text { care team' of a } \\
\text { hospital }\end{array}$ & with repeated mea- & patients: & $\begin{array}{l}\text { - improvements in } \\
\text { pain, nausea, } \\
\text { insomnia, }\end{array}$ \\
\hline in London. Activities: & surements and no & - PACA & $\begin{array}{l}\text { anorexia and } \\
\text { constipation } \\
\text { (all } \mathrm{P}<0.009 \text { ) }\end{array}$ \\
\hline $\begin{array}{l}\text { - advice/practical } \\
\text { support for } \\
\text { inpatients and }\end{array}$ & control group & (filled in by staff) & \\
\hline \multicolumn{4}{|l|}{ care providers } \\
\hline \multicolumn{4}{|l|}{ - family support } \\
\hline Field et al. '89[17]: & retrospective design & 40 terminal patients with & $\begin{array}{l}\text { after introduction } \\
\text { team: }\end{array}$ \\
\hline $\begin{array}{l}\text { ‘comprehensive } \\
\text { supportive care } \\
\text { team' in }\end{array}$ & with 2 comparison & multiple organ failure: & $\begin{array}{l}\text { - length of stay on } \\
\text { ICU reduced } \\
(P<0.01)\end{array}$ \\
\hline $\begin{array}{l}\text { Detroit. Activities: } \\
\text { see Campbell, } \\
\text { 1996. }\end{array}$ & groups (1 before and 1 & - clinical records & $\begin{array}{l}\text { - therapeutic } \\
\text { interventions } \\
\text { reduced }(P<0.01)\end{array}$ \\
\hline$[14]$ & after introduction team) & $\begin{array}{l}\text { - no significant effect on } \\
\text { survival rate }\end{array}$ & \\
\hline $\begin{array}{l}\text { Higginson et al. } \\
\text { '92[18]: }\end{array}$ & prospective design & $\begin{array}{l}227 \text { terminal patients } \\
\text { (ne- }\end{array}$ & $\begin{array}{l}\text { - total STAS- } \\
\text { scores improved } \\
\text { in } 83 \% \text {, didn't }\end{array}$ \\
\hline $\begin{array}{l}2 \text { 'palliative support } \\
\text { teams' of home } \\
\text { care }\end{array}$ & with repeated mea- & arly all with cancer): & $\begin{array}{l}\text { change in } 3 \% \text { and } \\
\text { worsened in } 13 \%\end{array}$ \\
\hline $\begin{array}{l}\text { organizations and } \\
\text { hospitals in } \\
\text { London }\end{array}$ & surements and no & - STAS & $\begin{array}{l}-15 \text { of } 17 \text { STAS- } \\
\text { items improved } \\
(P<0.00005)\end{array}$ \\
\hline and Kent. Activities: & control group & (filled in by staff) & $\begin{array}{l}\text { - scores regarding } \\
\text { family anxiety } \\
\text { and spiritual }\end{array}$ \\
\hline $\begin{array}{l}\text { - advice/practical } \\
\text { support for in- and }\end{array}$ & - clinical records & $\begin{array}{l}\text { needs didn't improve } \\
\text { significantly }\end{array}$ & \\
\hline \multicolumn{4}{|l|}{$\begin{array}{l}\text { outpatients and care } \\
\text { providers }\end{array}$} \\
\hline \multicolumn{4}{|l|}{ - family support } \\
\hline $\begin{array}{l}\text { Higginson \& Hearn } \\
\text { '97[19]: }\end{array}$ & prospective design & 695 terminal cancer & $\begin{array}{l}\text { after referral to } \\
\text { team: }\end{array}$ \\
\hline $\begin{array}{l}11 \text { 'palliative care } \\
\text { teams' of hospital } \\
\text { and }\end{array}$ & with repeated mea- & patients: & $\begin{array}{l}\text { - reduction of } \\
\text { STAS-score } \\
\text { regarding pain }\end{array}$ \\
\hline $\begin{array}{l}\text { home care } \\
\text { organisations in } \\
\text { Ireland and }\end{array}$ & surements and no & $-\mathrm{KPS}$ & $(P<0.0001)$ \\
\hline England. Activities: & control group & (filled in by staff) & \\
\hline $\begin{array}{l}\text { - advice/practical } \\
\text { support for in- and }\end{array}$ & - pain scale of STAS & & \\
\hline
\end{tabular}


Francke, A.L. Evaluative research on palliative support teams: a literature review. Patient Education and Counseling: 2000, 41(1), 83-91

\begin{tabular}{|c|c|c|c|}
\hline Authors/team & Design & \multirow[t]{3}{*}{ Sample/instruments } & \multirow[t]{3}{*}{ Outcomes } \\
\hline $\begin{array}{l}\text { outpatients and care } \\
\text { providers }\end{array}$ & (derived from patients) & & \\
\hline - family support & - clinical records & & \\
\hline $\begin{array}{l}\text { Hockley et al. } \\
\text { '88[20]: }\end{array}$ & prospective design & 26 terminal patients: & $\begin{array}{l}\text { after introduction } \\
\text { of team: }\end{array}$ \\
\hline $\begin{array}{l}\text { ‘symptom control } \\
\text { team' of a hospital } \\
\text { in }\end{array}$ & with repeated mea- & symptom list designed & $\begin{array}{l}\text { - number of } \\
\text { complaints of } \\
\text { relatives reduced }\end{array}$ \\
\hline London. Activities: & surements and no & by the researchers & $\begin{array}{l}\text { - anorexia, } \\
\text { sleeplessness, } \\
\text { coated or } \\
\text { infected }\end{array}$ \\
\hline $\begin{array}{l}\text { - advice for } \\
\text { inpatients and care } \\
\text { providers }\end{array}$ & control group (for & (derived from patients) & $\begin{array}{l}\text { mouths, pain and } \\
\text { pressure sores } \\
\text { seen in }\end{array}$ \\
\hline - family support & a small part of the & relatives: & $50 \%$ of patients \\
\hline - education/training & study a retrospective & - interview and Mood & $\begin{array}{l}\text { - fear about caring } \\
\text { for patient at } \\
\text { home and }\end{array}$ \\
\hline design with historical & Adjective Check List & $\begin{array}{l}\text { lack of information were } \\
\text { problems of relatives }\end{array}$ & \\
\hline $\begin{array}{l}\text { historical } \\
\text { comparison }\end{array}$ & - registrations of & $\begin{array}{l}\text { (no statistical testing of } \\
\text { outcomes) }\end{array}$ & \\
\hline group) & complaints & & \\
\hline $\begin{array}{l}\text { Jarvis \& Burge } \\
\text { '96[21]: }\end{array}$ & prospective design & 34 terminal patients: & $\begin{array}{l}\text { after introduction } \\
\text { of team/program: }\end{array}$ \\
\hline $\begin{array}{l}\text { 'palliative care team' } \\
\text { (part of a palliative }\end{array}$ & with repeated mea- & $\begin{array}{l}\text { - Symptom Distress } \\
\text { Scale }\end{array}$ & $\begin{array}{l}\text { - symptom scores } \\
\text { concerning } \\
\text { nausea, }\end{array}$ \\
\hline $\begin{array}{l}\text { care program) of a } \\
\text { hospital in } \\
\text { Quebec. }\end{array}$ & surements and no & (derived from patients) & $\begin{array}{l}\text { insomnia, fatigue, } \\
\text { bowel problems, } \\
\text { outlook, }\end{array}$ \\
\hline Activities: & control group & relatives and care & $\begin{array}{l}\text { cough and } \\
\text { breathing } \\
\text { increased } \\
\text { (all } \mathrm{P}<0.02 \text { ) }\end{array}$ \\
\hline $\begin{array}{l}\text { - advice/practical } \\
\text { support for in- and }\end{array}$ & providers: & $\begin{array}{l}\text { - relatives and care } \\
\text { providers were } \\
\text { satisfied }\end{array}$ & \\
\hline $\begin{array}{l}\text { outpatients and care } \\
\text { providers (also }\end{array}$ & several scales & with team & \\
\hline $\begin{array}{l}\text { including an } \\
\text { inpatient unit) }\end{array}$ & & & \\
\hline - family support & & & \\
\hline $\begin{array}{l}\text { Lonberger et al. } \\
\text { '97[22]: }\end{array}$ & retrospective design & 10 terminal patients: & $\begin{array}{l}\text { after referral to } \\
\text { team: }\end{array}$ \\
\hline $\begin{array}{l}\text { 'palliative care team' } \\
\text { of the University of }\end{array}$ & with repeated mea- & - clinical and financial & $\begin{array}{l}\text { - reduction of daily } \\
\text { charges }\end{array}$ \\
\hline
\end{tabular}


Francke, A.L. Evaluative research on palliative support teams: a literature review. Patient Education and Counseling: 2000, 41(1), 83-91

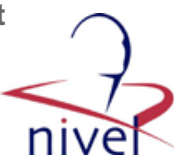

\begin{tabular}{|c|c|c|c|}
\hline Authors/team & Design & Sample/instruments & Outcomes \\
\hline & & & $(P<0.02)$ \\
\hline $\begin{array}{l}\text { Missouri-Columbia } \\
\text { Hospitals \& Clinics }\end{array}$ & surements and no & records & $\begin{array}{l}\text { particularly } \\
\text { laboratory and } \\
\text { radiology } \\
\text { charges }\end{array}$ \\
\hline Activities: & control group & & \\
\hline $\begin{array}{l}\text { - advice/practical } \\
\text { support for } \\
\text { inpatients }\end{array}$ & & & \\
\hline and care providers & & & \\
\hline - family support & & & \\
\hline $\begin{array}{l}\text { McWhinney et al. } \\
\text { '94[23]: }\end{array}$ & prospective & $\begin{array}{l}146 \text { terminal cancer } \\
\text { patients: }\end{array}$ & $\begin{array}{l}\text { after referral to } \\
\text { team: }\end{array}$ \\
\hline $\begin{array}{l}\text { 'palliative care home } \\
\text { support team' of a }\end{array}$ & randomized waiting & $-M P Q$ & $\begin{array}{l}\text { - no significant } \\
\text { improvements of } \\
\text { pain, nausea }\end{array}$ \\
\hline $\begin{array}{l}\text { hospital in Ontario. } \\
\text { Activities: }\end{array}$ & list control group & $\begin{array}{l}\text { - Melzack nausea } \\
\text { questionnaire }\end{array}$ & $\begin{array}{l}\text { or quality of life of } \\
\text { patients }\end{array}$ \\
\hline $\begin{array}{l}\text { - advice/practical } \\
\text { support for } \\
\text { outpatients }\end{array}$ & design with repeated & - functional living index & $\begin{array}{l}\text { - no significant } \\
\text { improvement of } \\
\text { care givers' }\end{array}$ \\
\hline and care providers & measurements & 74 relatives: & psychic health \\
\hline $\begin{array}{l}\text { - coordination of } \\
\text { care }\end{array}$ & - CES-D scale & & \\
\hline
\end{tabular}

